\title{
SOCIAL NETWORK GROUP KUBE MEKAR SARI KELURAHAN GUNTUNG, BONTANG CITY
}

\section{JARINGAN SOSIAL KELOMPOK KUBE MEKAR SARI KELURAHAN GUNTUNG, KOTA BONTANG}

\author{
Putri Damayanti ${ }^{1}$, Martinus Nanang ${ }^{2}$ \\ Universitas Mulawarman, Indonesia
}

Email Correspondence: putri0dama4@gmail.com

\begin{abstract}
:
KUBE is one of the programs launched by the Bontang city government in poverty reduction. KUBE in Bontang City was first formed in 2013. Based on data from the Bontang City Social Service in 2018, the number of KUBE in Bontang City reached 282 groups. The large number of KUBE can be a big hope for the local government in improving the welfare of the community. However, the implementation of the KUBE program in the city of Bontang has not met the government's expectations. This is made clear by the large number of KUBE in the city of Bontang that are not developing or moving towards independence. However, in the city of Bontang there is one KUBE that stands out the most, namely Mekar Sari. KUBE Mekar Sari is the best group at city, provincial to national levels. This study aims to determine how the process behind the success of KUBE Mekar Sari in achieving independence and the success of KUBE Mekar Sari can be seen from two sides, namely social and economic, and there are several factors that KUBE independence has a network of connections with each other.
\end{abstract}

Keywords: Factors of Independence, KUBE Mekar Sari, Process of Independence

\begin{abstract}
ABSTRAK:
KUBE merupakan salah satu program yang dicanangkan oleh pemerintah kota Bontang dalam hal penanggulangan kemiskinan. KUBE di kota Bontang pertama kali dibentuk pada tahun 2013. Berdasarkan data Dinas Sosial kota Bontang pada tahun 2018, jumlah KUBE di kota Bontang mencapai 282 kelompok. Kuantitas KUBE yang tergolong banyak dapat menjadi harapan besar bagi pemerintah setempat dalam meningkatkan kesejahteraan masyarakat. Akan tetapi implementasi program KUBE di kota Bontang belum sesuai dengan harapan pemerintah. Hal tersebut diperjelas dengan banyaknya jumlah KUBE di kota Bontang yang tidak berkembang atau bergerak menuju kemandirian. Meskipun demikian, di kota Bontang terdapat satu KUBE yang paling menonjol dibanding dengan yang lainnya yaitu Mekar Sari. KUBE Mekar Sari adalah kelompok terbaik tingkat kota, provinsi hingga nasional. Penelitian ini bertujuan untuk mengetahui bagaimana proses di balik keberhasilan KUBE Mekar Sari dalam mencapai kemandirian dan keberhasilan KUBE Mekar Sari dapat dilihat dari dua sisi yaitu sosial dan ekonomi, dan ada beberapa faktor kemandirian KUBE memilki jaringan koneksi satu sama lain.
\end{abstract}

Kata Kunci: Faktor Kemandirian, KUBE Mekar Sari, Proses Kemandirian,

\begin{tabular}{l|l|l}
\hline Article Info & & \\
\hline Received & $:$ & July 2020 \\
\hline Accepted & $:$ & July 2020 \\
\hline Published & $:$ & July 2020 \\
\hline DOI & $:$ & https://doi.org/10.30872/psd.v1i2.22 \\
\hline
\end{tabular}

\section{Copyright and License}

Authors retain copyright and grant the journal right of first publication with the work simultaneously licensed under a Creative Commons Attribution 4.0 International License that allows others to share the work with an acknowledgment of the work's authorship and initial publication in this journal. 


\section{PENDAHULUAN}

KUBE merupakan salah satu program yang dicanangkan oleh pemerintah kota Bontang dalam hal penanggulangan kemiskinan. Program dengan pendekatan pemberdayaan ini memberikan wewenang sepenuhnya kepada kelompok masyarakat miskin untuk mengelola, mengembangkan, dan menikmati hasilhasilnya. Sedangkan pemerintah hanya memfasilitasi agar KUBE dapat berjalan dengan baik. KUBE di kota Bontang pertama kali dibentuk pada tahun 2013. Berdasarkan data Dinas Sosial kota Bontang pada tahun 2018, jumlah KUBE di kota Bontang mencapai 282 kelompok yang terbagi menjadi tiga kategori yaitu tumbuh, pengembangan dan mandiri. Dengan kuantitas KUBE yang tergolong banyak dapat menjadi harapan besar bagi pemerintah setempat dalam meningkatkan kesejahteraan masyarakat. Namun realitas yang terjadi, implementasi program KUBE di kota Bontang belum sesuai dengan apa yang di harapkan oleh pemerintah. Hal tersebut diperjelas dengan banyaknya jumlah KUBE di kota Bontang yang tidak berkembang atau bergerak menuju kemandirian yaitu hanya terdapat enam KUBE mandiri dari 282 kelompok yang ada.

Kemandirian dari sebuah KUBE merupakan harapan bagi pemerintah, dimana sebuah kelompok mampu mengambil keputusannya sendiri dalam langkah perjalanan mereka mengapai tujuan yang lebih baik. Oleh karena itu untuk melihat bagaimana kemandirian dalam sebuah kelompok, proses adalah hal yang terpenting. Proses merupakan state of becoming, yaitu keadaan dimana seseorang atau kelompok terusmenerus berusaha untuk mencapai sesuatu. Proses sendiri bersifat dinamis dan tidak statis, sehingga tidak membuat seseorang atau kelompok terjebak ke dalam situasi ideal tertentu. Jika berbicara mengenai proses maka hal tersebut pasti berkaitan dengan hasil. Hasil merupakan sesuatu yang dicapai dari proses, sedangkan proses adalah hal yang selalu melatarbelakangi sebuah hasil. Dengan proses, kita mampu melihat bagaimana dinamika perkembangan suatu kelompok dari kondisi awal hingga berkembangnya kelompok mencapai tujuan. Kemudian dari proses itu, kita akan menemukan berbagai faktor pendukung dan penghambat yang selalu menyertainya, sehingga akan ditemukan alasan dibalik keberhasilan atau kegagalan dari kelompok itu.

Meskipun di kota Bontang terdapat banyak KUBE yang gagal mencapai kemandirian, di kota Bontang sendiri terdapat satu KUBE yang paling menonjol dibandingkan dengan yang lainnya yaitu KUBE Mekar Sari. Kelompok Usaha Bersama (KUBE) Mekar Sari adalah kelompok terbaik tingkat kota, provinsi hingga nasional. Tidak hanya itu, Mekar Sari juga dianggap sebagai role model bagi KUBE lain yang ada di kota Bontang dan juga merupakan salah satu KUBE yang berhasil mencapai kemandirian. Penelitian ini akan berfokus pada proses perjalanan yang dilalui oleh KUBE Mekar Sari sebelum mencapai kemandirian atau bisa disebut sebagai proses kemandiran KUBE Mekar Sari.

\subsection{Kerangka Konseptual}

Dalam rangka mengurangi kemiskinan dan meningkatkan kesejahteraan masyarakat miskin, pemerintah telah mengembangkan kelompok sebagai salah satu media pemberdayaan masyarakat yang dikenal sebagai KUBE. Keberadaan kelompok dalam setiap komunitas merupakan sesuatu yang sangat dibutuhkan di dalam mengorganisir dan memecahkan masalah yang dihadapi oleh komunitas tersebut. Melalui KUBE diharapkan kesejahteraan masyarakat miskin dapat terentaskan paling tidak dikurangi. Keberhasilan Kelompok Usaha Bersama KUBE) dalam menjalankan fungsinya adalah kemandirian. Dimana dalam mewujudkan kemandirian itu memerlukan proses yang cukup panjang. Menurut KBBI proses adalah runtunan perubahan (peristiwa) dalam perkembangan sesuatu, yang secara umum didefinisikan sebagai serangkaian langkah sistematis, atau tahapan yang jelas dan dapat ditempuh berulangkali untuk mencapai hasil yang diinginkan. Banyak sekali contoh proses yang terjadi di dalam kehidupan kita, baik proses yag dilakukan oleh seorang individu ataupun sebuah kelompok.

Sebagai sebuah kelompok yang menjadi wadah bagi masyarakat miskin untuk meningkatkan taraf hidupnya, proses dari KUBE merupakan hal terpenting. Mengacu pada definisi proses, proses dapat dikatakan sebagai kejadian-kejadian yang menjadi latar belakang dibalik sebuah keberhasilan. Gambaran akan proses tersebut pertama kali dilihat pada bagaimana proses pembentukan awal KUBE. Proses pembentukan KUBE merupakan suatu hal yang penting karena sangat terkait dengan proses pengembangan selanjutnya. Proses pembentukan KUBE berkaitan dengan bagaimana latar belakang terbentuknya KUBE, bagiamana visi dan misi, bagaimana struktur kepengurusan, dan jenis usaha kelompok. Menurut Jamaluddin dalam Joyakin (2006) kelompok yang diprakarsai oleh faktor eksternal khususnya pihak pemerintah menunjukkan perkembangan yang kurang berhasil dibandingkan dengan kelompok yang diprakarsai oleh masyarakat itu sendiri. Kemudian latar belakang gagasan pembentukan sebuah kelompok berpengaruh terhadap keberhasilan dan keberlanjutan dari kelompok tersebut. Setelah proses pembentukan KUBE maka akan digambarkan bagaimana proses perkembangan KUBE yang dilihat pada dua aspek yaitu perkembangan usaha yang mencakup pada perkembangan inovasi produk, pemasaran, jumlah produksi, aset dan perkembangan kemitraan yang terkait akan perkembangan relasi kerjasama KUBE di luar kelompok.

Dalam serangkaian proses pembentukan dan perkembangan KUBE, peneliti akan menggali bagaimana cara KUBE Mekar Sari mengembangkan usaha dan kemitraanya serta cara KUBE mengatasi permasalahan 
yang timbul selama kedua proses tersebut berlangsung. Setelah itu peneliti akan mengidentifikasi faktorfaktor apa saja yang mempengaruhi proses perkembangan KUBE dalam mencapai kemandirian dan mengidentifikasi faktor utama pendukung keberhasilan KUBE mencapai kemandirian kelompok. Dengan melihat keseluruhan proses tersebut maka akan diperoleh konsep kemandirian KUBE yang tergambar atas serangkaian proses yang saling berkoneksi antara satu dengan yang lainnya. Kemudian gambaran terkait kerangka alur pemikiran dalam penelitian ini termuat pada gambar dibawah ini.:

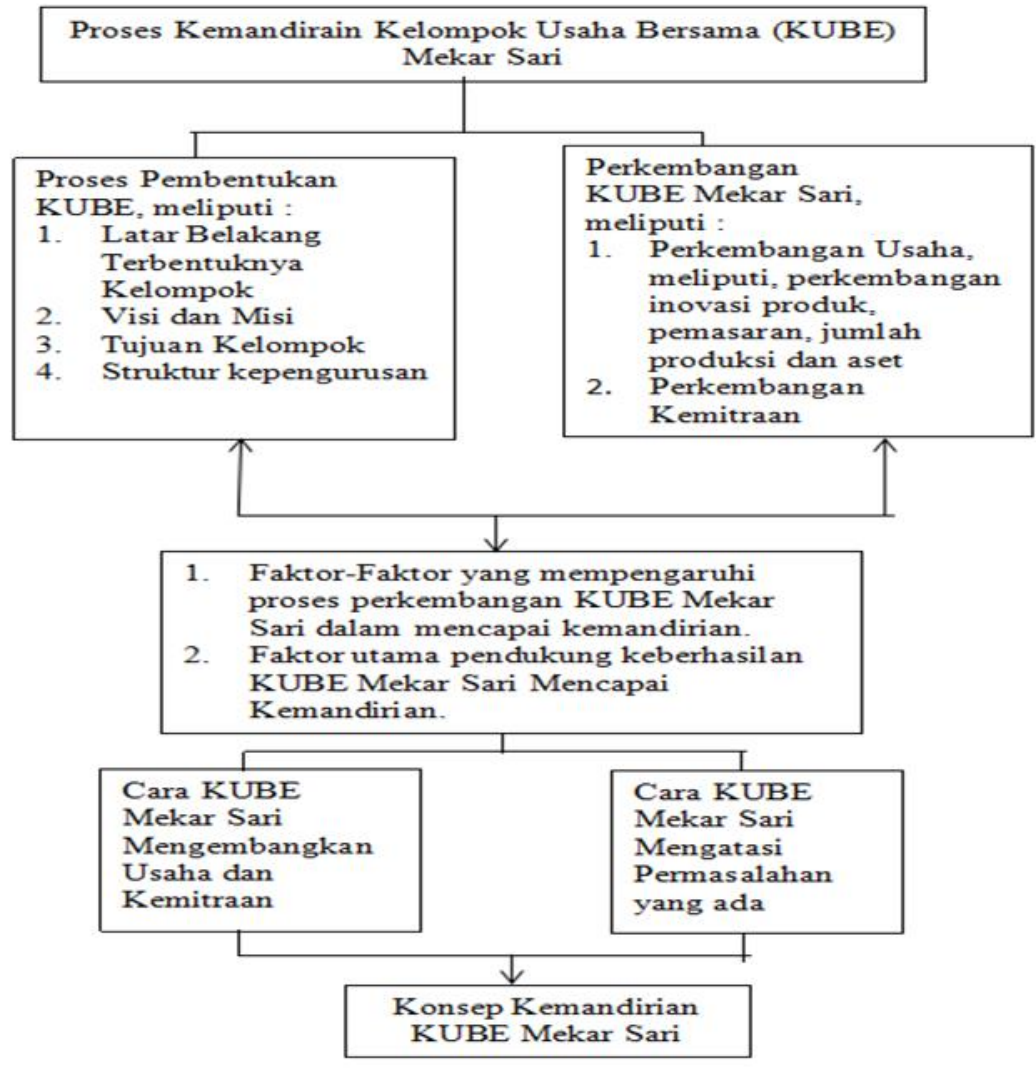

Figure 1 Kerangka Alur Proses Kemandirian KUBE

\section{METODE}

Penelitian ini menggunakan pendekatan deskriptif kualitatif. Subyek penelitian adalah pengelola, anggota, dan pendamping KUBE Mekar Sari. Pengumpulan data menggunakan wawancara mendalam, observasi partisipasi aktif selama enam bulan di KUBE Mekar Sari yang juga merupakan kegiatan pra penelitian yang dilakukan oleh peneliti, pengumpulan dokumen yang bersumber dari dokumen-dokumen kelompok dan artikel berita online lokal hingga nasional serta peneliti juga melaksanakan Focus Group Discussion (FGD) bersama anggota Kelompok Usaha Bersama (KUBE) Mekar Sari sebanyak satu kali. Peneliti melakukan penelitian dibantu pedoman wawancara, pedoman observasi, dan pedoman dokumentasi. Teknik analisis data yang digunakan adalah reduksi data, penyajian data, dan penarikan kesimpulan. Triangulasi yang digunakan yaitu triangulasi sumber dan teknik. Seluruh kegiatan penelitian dilakukan oleh peneliti berlangsung selama delapan bulan, dengan pra penelitian enam bulan dan penelitian setelah pengajuan proposal selama dua bulan, hal ini dilakukan oleh peneliti guna memperoleh gambaran mendalam terkait proses kemandirian dari KUBE Mekar Sari.

\section{HASIL DAN PEMBAHASAN}

Alur Proses Pembentukan KUBE Mekar Sari :

1. Tahun 2011, lokasi KUBE Mekar Sari yaitu RT 07 Kelurahan Guntung memperoleh predikat sebagai wilayah terjorok Kota Bontang.

2. Tahun 2011-2013-an, Dasa Wisma Mekar Sari melakukan gerakan penyadaran mengenai kebersihan lingkungan pada RT 07 selama kurang lebih tiga tahun. 
3. Tahun 2013-an, Dasa Wisma Mekar Sari mulai memanfaatkan sampah sebagai pupuk kompos. Kemudian membentuk Kelompok Perempuan Mekar Sari (KPMS) sebagai wadah pengembangan usaha.

4. Tahun 2014-an Kelompok Perempuan Mekar Sari (KPMS) mendapat bantuan KUBE dari Dinas Sosial Kota Bontang sehingga berubahnya KPMS menjadi KUBE Mekar Sari.

5. Bulan April tahun 2014 terbentuk Kelompok Usaha Bersama (KUBE) Mekar Sari.

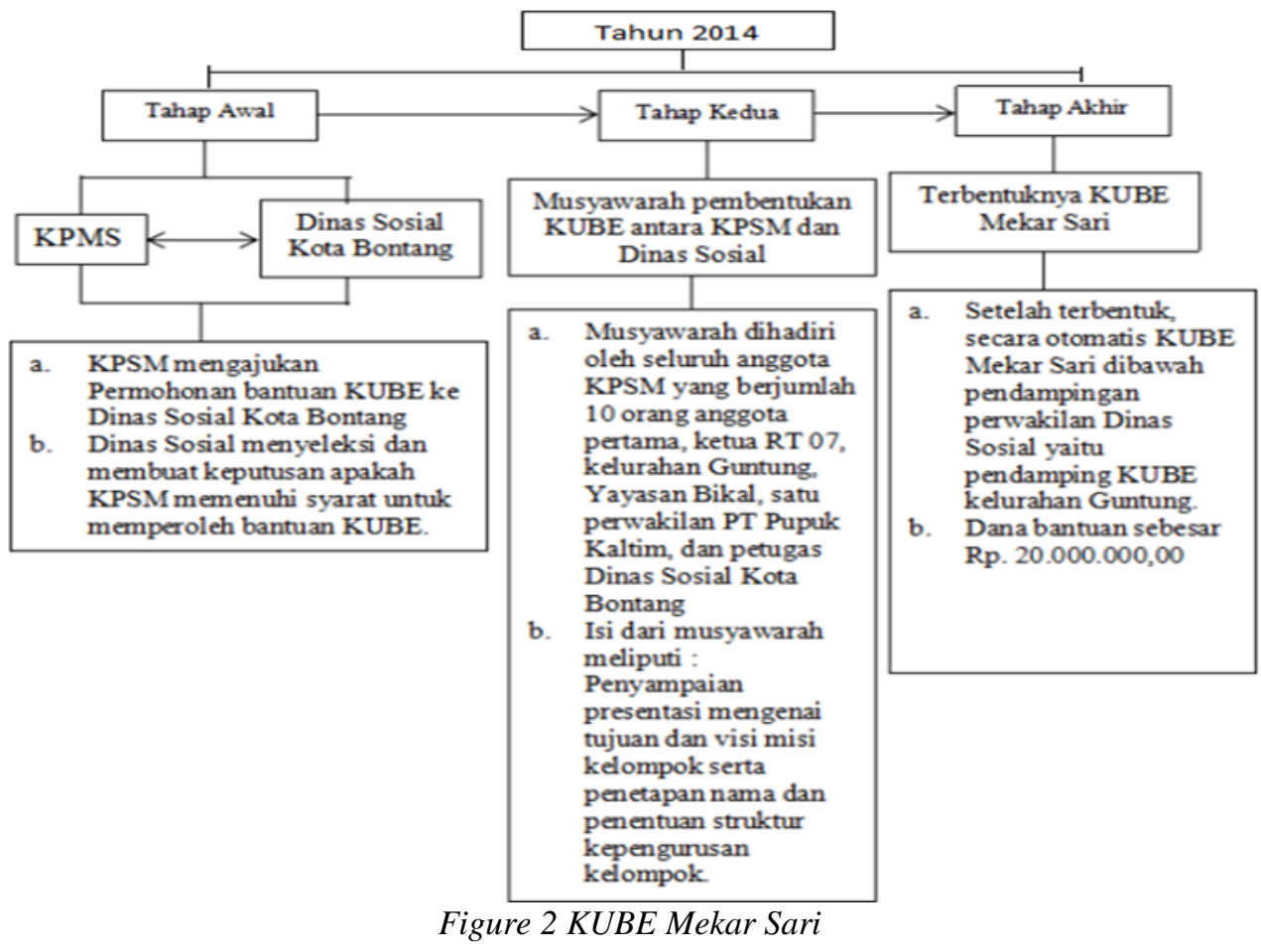

Keterangan Alur Proses Pembentukan KUBE Mekar Sari :

a. Sebelum membentuk KUBE, KPMS merupakan kelompok perempuan yang tergabung pada kelompok mitra binaan PT Pupuk Kaltim dan Yayasan Bikal Karya Lestari,

b. Guna memperoleh modal usaha KPMS mengajukan proposal pada Dinas Sosial kota Bontang,

c. Bantuan program KUBE dapat diberikan dengan persyaratan kelompok harus berbentuk KUBE, hal inilah yang melatar belakangi berubahnya nama Kelompok Perempuan Mekar Sari (KPMS) menjadi Kelompok Usaha Bersama (KUBE) Mekar Sari

d. Langkah kelompok dalam memperoleh modal usaha di arahkan oleh Yayasan Bikal Karya Lestari yang juga merupakan pendamping dari KPMS agar kelompok dapat mengembangkan usahanya,

e. Anggota awal dari KUBE Mekar Sari berjumlah 10 orang yaitu sebagian jumlah anggota dari KPMS, dimana hal ini dilakukan guna melengkapi persayaratan KUBE pada masa itu dengan jumlah maksimal anggota kelompok berjumlah 10 orang. Akan tetapi setelah terbentuk, sisa anggota KPMS yang lain bergabung pada kelompok sehingga anggota KUBE berjumlah 20 orang. Kemudian setelah terbentuk dana bantuan KUBE dapat dicairkan dua hari kemudian,

f. Setelah berbentuk KUBE, Yayasan Bikal Karya Lestari tetap mendampingi kelompok hingga lima tahun kedepan. Meskipun KUBE Mekar Sari telah memiliki pendamping dari Dinas Sosial kota Bontang. 


\subsection{Rencana Pengembangan Usaha KUBE Mekar Sari}

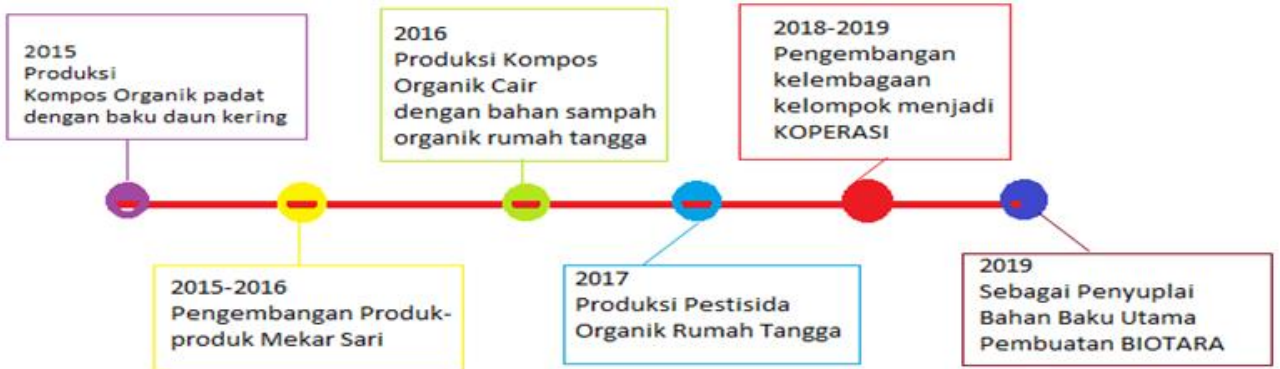

Figure 3 Pengembangan Usaha KUBE Mekar Sari

\subsection{RENSTRA KUBE Mekar Sari Tahun 2015-2019}

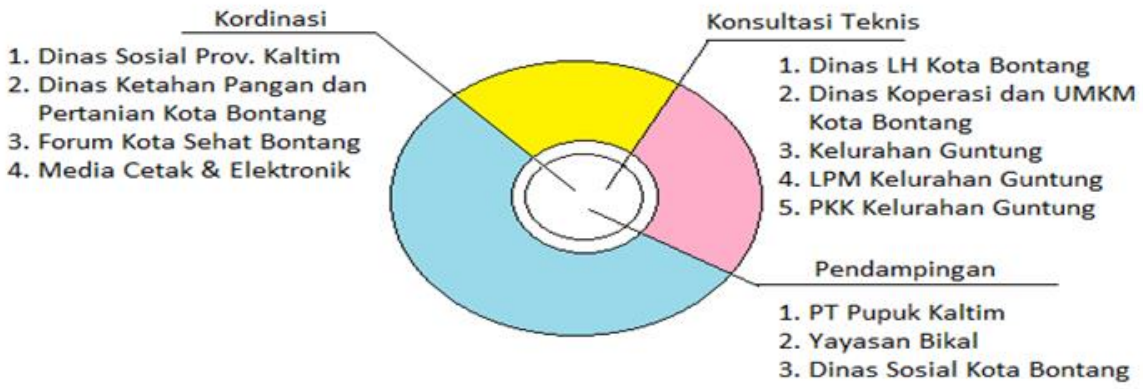

Figure 4 Rencana dan Strategi KUBE Mekar Sari

\subsection{Rencana Pengembangan Usaha KUBE Mekar Sari}

KUBE Mekar Sari memiliki jaringan kemitraan yang cukup luas, disetiap kemitraan yang telah terjalin dengan kelompok terbagi menjadi tiga kategori yaitu pendampingan, kordinasi dan konsultasi teknis. Hal ini dilakukan oleh kelompok guna mempermudah dalam mengorganisir kemitraan yang telah ada. Pendampingan adalah bentuk kemitraan utama bagi kelompok, kemitraan kategori pendampingan hanya berisi instansi yang senantiasa mendampingi kelompok dalam mengembangkan usaha guna mencapai kemandirian. Kemudian kemitraan kategori kordinasi hanya berisi instansi yang senantiasa menjalin komunikasi dengan KUBE dalam bidang perwujudan program penyelenggaraan event yang diadakan baik oleh oleh kelompok ataupun dari instansi tersebut. Misalnya saja dalam rangka perwujudan program Rumah Pangan Lestari (RPL) Dinas Ketahanan Pangan kota Bontang berkordinasi dengan KUBE Mekar Sari. Sedangkan kemitraan kategori konsultasi teknis yaitu hanya berisi instansi yang bermanfaat bagi KUBE dalam bidang teknis pengembangan usaha dan perwujudan perencanaan program kelompok, misalnya saja kelompok berencana untuk membangun koperasi maka untuk terkait hal-hal teknis mengenai koperasi, KUBE akan berkonsultasi dengan Dinas Koperasi dan UMKM kota Bontang.

\subsection{Perkembangan Inovasi Produk Usaha dan Pendapatan KUBE Mekar Sari}

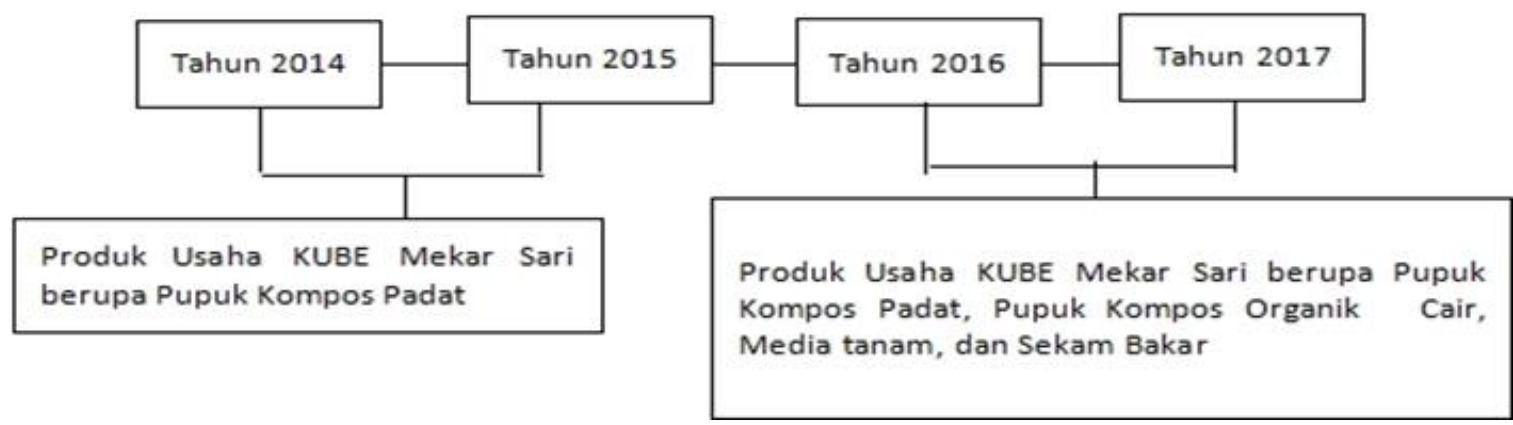

Figure 5 Inovasi Produk Usaha dan Pendapatan KUBE Mekar Sari 
Tabel 1. Pendapatan KUBE Mekar Sari dalam tiga tahun

\begin{tabular}{lll}
\hline Tahun & Pendapatan KUBE mekar sari & $\begin{array}{l}\text { Rata- Rata Pendapatan Anggota } \\
\text { KUBE Mekar sari }\end{array}$ \\
\hline 2015 & Rp. 1. 410. 000,00 & Rp 335.000,00 \\
2016 & Rp 11.405. 000,00 & Rp 475.000,00 \\
2017 & Rp 12.155.000,00 & Rp. 650.000,00 \\
\hline
\end{tabular}

Sumber : Profil KUBE Mekar Sari

\subsection{Faktor yang Mempengaruhi Perkembangan KUBE Mekar Sari dalam Mencapai Kemandirian Kelompok}

Berdasarkan hasil identifikasi yang dilakukan oleh peneliti, terdapat empat faktor yang mempengaruhi proses perkembangan Kelompok Usaha Bersama (KUBE) Mekar Sari dalam mencapai kemandirian kelompok. Empat faktor ini dapat disebut sebagai faktor kedinamisan KUBE yang meliputi:

1. manajemen pengelolaan kelompok, (

2. jaringan kemitraan,

3. peran pendamping KUBE, dan

4. inovasi usaha. Alasan kenapa empat faktor ini di identifikasi sebagai faktor kedinamisan KUBE Mekar Sari, karena dengan adanya faktor-faktor tersebut membuat KUBE Mekar Sari akan dinamis dan semakin dinamis.

\subsection{Faktor Utama Pendukung Keberhasilan KUBE Mekar Sari Mencapai Kemandirian}

Berdasarkan hasil identifikasi yang dilakukan oleh peneliti, terdapat empat faktor utama pendukung keberhasilan KUBE Mekar Sari dalam mencapai kemandirian kelompok. Empat faktor tersebut meliputi:

1. kekompakan kelompok,

2. kemitraan dengan Yayasan Bikal Karya Lestari dan PT Pupuk Kaltim,

3. pendamping CSR KUBE Mekar Sari dan

4. kepemimpinan ketua kelompok.

Tahun 2011 tepat dimana wilayah RT 07 kelurahan Guntung memperoleh predikat sebagai wilayah terjorok kota Bontang adalah titik awal yang membentuk KUBE Mekar Sari hingga berhasil sampai saat ini. Sejarah awal yang membentuk ikatan sosial diantara ibu-ibu Dasa Wisma Mekar Sari dan munculnya ide pembuatan pupuk kompos. Sebelum menjadi KUBE pada tahun 2014, Mekar Sari merupakan kelompok perempuan yang disebut sebagai KPMS, sebuah kelompok yang sejak awal telah mengikrarkan diri untuk meningkatkan perekonomian rumah tangga mereka melalui produksi usaha rumahan berupa pupuk kompos. Kemudian guna memperoleh modal usaha, KPMS mengajukan permohonan bantuan KUBE pada Dinas Sosial kota Bontang sehingga terbentuklah KUBE Mekar Sari pada tahun 2014. Sebelum menjadi KUBE, Mekar Sari telah didampingi sebelumnya oleh Yayasan Bikal dan PT Pupuk Kaltim pada tahun 2013. Saat pembentukan KUBE, Mekar Sari telah menetapkan kemandirian sebagai visi kelompok sehingga untuk mewujudkan hal tersebut KUBE Mekar Sari menyusun rencana pengembangan usaha kelompok atau biasa disebut sebagai RENSTRA yang dijadikan pedoman hingga tahun 2019. Penyusunan RESTRA dilakukan agar kelompok memiliki perencanaan yang jelas atas tujuan yang telah mereka tetapkan. Bagi KUBE Mekar Sari perencanaan yang jelas dan terencana akan memudahkan kelompok untuk mengidentifikasi kelemahan dan kelebihan yang mereka miliki selama proses perjalanan mereka menuju kemandirian.

Perjalanan KUBE Mekar Sari dalam mencapai kemandirian penuh dengan masalah, seperti hampir bubarnya kelompok, hilangnya semangat anggota, sulitnya memasarkan produk dan terbatasnya modal usaha tidak membuat kelompok menyerah untuk menggapai tujuan yaitu kemandirian. Tahun 2014 sampai dengan 2015, KUBE Mekar Sari memproduksi pupuk kompos padat. Namun seiring berjalannya waktu kelompok mampu memproduksi beraneka ragam produk usaha diantaranya pestisida nabati, pupuk kompos organik cair, media tanam, sekam bakar dan tentu saja pupuk kompos padat. Dengan perkembangan inovasi produk usaha yang meningkat membuat penghasilan kelompok juga ikut meningkat, hal itu dibuktikan dengan meningkatnya pendapatan kelompok dari tahun 2015 sampai dengan 2017 (termuat pada tabel diatas). Mekar Sari memiliki manajemen pengelolaan yang baik dan terencana, kemitraan yang luas serta berkembangnya inovasi produk usaha membuat mereka berhasil mencapai kemandirian. Tidak hanya itu, KUBE Mekar Sari bahkan di nobatkan sebagai KUBE terbaik tingkat nasional pada tahun 2016 


\subsection{Interkoneksi Faktor-Faktor Kemandirian KUBE Mekar Sari}

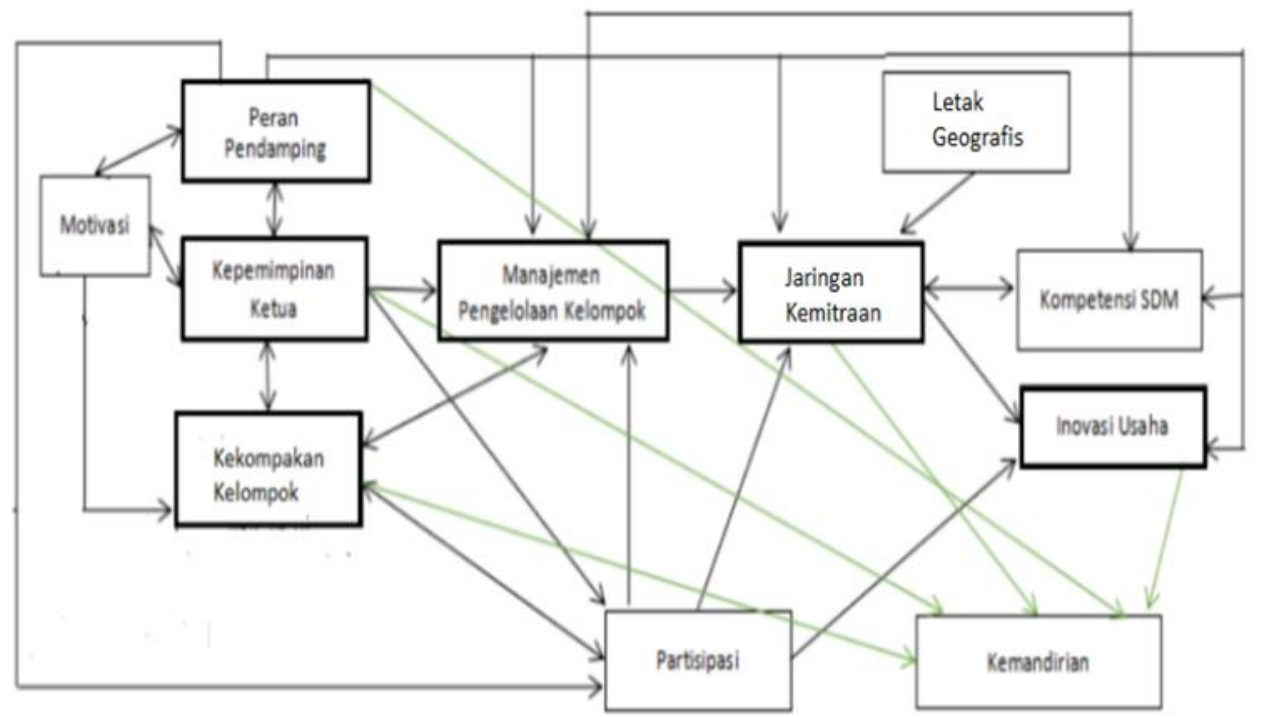

Figure 6 Alur Interkoneksi Faktor-faktor Kemandirian KUBE Mekar Sari

Gambar alur interkoneksi di atas menggambarkan bagaimana setiap faktor terhubung satu sama lain sehingga membentuk konsep-konsep Kelompok Usaha Bersama (KUBE) Mekar Sari dalam mewujudkan kemandirian. KUBE Mekar Sari dalam proses perjalanannya mencapai kemandirian ditentukan oleh enam faktor diantaranya peran pendamping, jaringan kemitraan, kekompakan kelompok, manajemen pengelolaan kelompok, kepemimpinan ketua kelompok dan inovasi usaha. Sedangkan faktor sekunder meliputi aspek geografis dan kompetensi SDM. Kemudian motivasi dan partisipasi dianggap sebagai sebuah hal yang memang harus dimiliki oleh kelompok secara umum.

Pendamping dalam perannya meningkatkan kemampuan Sumber Daya Manusia (SDM) anggota kelompok, membantu kelompok dalam penyusunan rencana kerja, monitoring dan evaluasi. Kemudian kemitraan KUBE membantu kelompok dalam meningkatkan modal dan pemasaran. Sedangkan inovasi usaha membantu kelompok dalam meningkatkan pendapatan. Selanjutnya manajemen pengelolaan kelompok yang terarah dan terencana akan mempermudah kelompok dalam penyusunan langkah-langkah kegiatan yang akan dilakukan. Terakhir adalah kepemimpinan ketua kelompok yang bersifat multifungsi yaitu sebagai penguat kelompok, pengarah anggota, penggerak kegiatan serta menyelesaikan konflik-konflik internal.

Letak geografis dan kompetensi Sumber Daya Manusia (SDM) dalam proses kemandirian KUBE Mekar Sari berposisi sebagai faktor sekunder (bukan faktor utama). Lokasi KUBE Mekar Sari yang terletak di daerah buffer zone PT Pupuk Kaltim menjadikan mereka sebagai kelompok mitra binaan CSR PKT, namun jika sebuah kelompok memiliki kemauan dalam memperluas kemitraan tanpa aspek geografis pun tetap akan bisa mengembangkan jaringan kemitraannya. Kemudian kompetensi Sumber Daya Manusia (SDM) anggota kelompok bukanlah sesuatu yang harus dimiliki oleh kelompok mandiri sejak awal. Kompetensi SDM akan meningkat apabila kelompok memiliki ke enam faktor utama yang telah di sebutkan di atas.

\section{KESIMPULAN}

Kelompok Usaha Bersama Mekar Sari merupakan salah satu KUBE mandiri di kota Bontang. Kelompok yang dikenal dengan berbagai macam prestasi ini pertama kali dibentuk pada tahun 2014 dan mencapai kemandirian pada tahun 2017. Tidak hanya prestasi, KUBE Mekar Sari juga dikenal akan keaktifannya dalam memberdayakan masyarakat. Bentuk pemberdayaan yang dilakukan meliputi penyuluhan kebersihan lingkungan, pelatihan pembuatan kompos, pelatihan public speaking, pelatihan pemanfaatan sampah menjadi produk inovatif dan pelatihan pengelolaan administrasi bagi KUBE.

Berdasarkan hasil penelitian mengenai proses kemandirian KUBE Mekar Sari, peneliti memperoleh gambaran konsep kemandirian yang tertuang kedalam beberapa poin dibawah ini:

a. Pada saat awal pembentukan kelompok, KUBE Mekar Sari telah menetapkan tujuan yang ingin di capai yaitu kemandirian. Bagi KUBE Mekar Sari tujuan awal kelompok yang jelas akan memberikan arahan yang jelas pula, sehingga akan mempermudah kelompok dalam merumuskan perencanaan kegiatan guna mewujudkan tujuan tersebut. Setiap proses. perumusan tujuan, 
peraturan, rencana-rencana kerja serta pengambilan keputusan, KUBE Mekar Sari senantiasa melaksanakan musyawarah yang melibatkan seluruh anggota kelompok. KUBE memiliki pedoman kelompok yaitu "berbuat bersama, berperan setara", sehingga dalam perjalannya, anggota kelompok menjadi kompak. Kemudian dalam proses pengembangan kelompok, KUBE Mekar Sari memiliki manajemen pengelolaan kelompok yang jelas dan terencana. KUBE memiliki rencana strategis kelompok, manajemen peningkatan kualitas anggota, penyelesaian konflik yang efektif dan di dukung dengan eksistensi pendamping, semangat anggota untuk maju serta memanfaatkan potensi yang dimiliki sehingga terciptanya kemandirian

b. Keberhasilan KUBE Mekar Sari dapat dilihat dari dua sisi, yaitu keberhasilan yang berkaitan dengan aspek sosial dan keberhasilan yang berkaitan dengan aspek ekonomi. Keberhasilan KUBE Mekar Sari dalam aspek sosial meliputi;

1. kerjasama sama anggota kelompok terjalin dengan baik,

2. pengelolaan Iuran Kesetiakawanan Sosial (IKS) KUBE Mekar Sari berjalan dengan baik,

3. tingkat partisipasi anggota tergolong cukup tinggi dalam berbagai kegiatan,

4. kelompok memiliki manajemen perencanaan usaha yang terarah,

5. kelompok mampu mengatasi setiap masalah, baik secara internal maupun eksternal,

6. Adanya inovasi usaha. Sedangkan keberhasilan KUBE Mekar Sari dalam aspek ekonomi meliputi; modal kelompok berkembang di setiap tahun, pendapatan kelompok meningkat,anggota kelompok memiliki tabungan, Adanya transparansi dalam

c. Kedinamisan KUBE Mekar Sari dalam mencapai kemandirian dipengaruhi oleh empat faktor yaitu manajemen pengelolaan kelompok, kemitraan, peran pendamping dan inovasi usaha. Kemudian ada empat faktor utama pendorong keberhasilan KUBE Mekar Sari dalam mencapai kemandirian kelompok, meliputi kekompakan kelompok, kemitraan dengan Yayasan Bikal Karya Lestari dan PT Pupuk Kaltim, pendamping CSR KUBE Mekar Sari dan kepemimpinan ketua kelompok.

d. KUBE Mekar Sari dalam proses perjalanannya mencapai kemandirian ditentukan oleh faktor kemandirian KUBE, enam faktor utama diantaranya peran pendamping, kemitraan, kekompakan kelompok, manajemen pengelolaan kelompok, kepemimpinan ketua kelompok dan inovasi usaha. Sedangkan faktor sekunder meliputi aspek geografis dan kompetensi SDM. Kemudian motivasi dan partisipasi dianggap sebagai sebuah hal yang memang harus dimiliki oleh kelompok secara umum. Seluruh faktor kemandirain KUBE memilki jaringan koneksi satu sama lain misalnya saja pendamping dalam perannya meningkatkan kemampuan Sumber Daya Manusia (SDM) anggota kelompok, membantu kelompok dalam penyusunan rencana kerja, monitoring dan evaluasi. Kemudian kemitraan KUBE membantu kelompok dalam meningkatkan modal, pemasaran, sedangkan inovasi usaha membantu kelompok dalam meningkatkan pendapatan. Selanjutnya manajemen pengelolaan kelompok yang tererah dan terencana akan mempermudah kelompok dalam penyusunan langkah-langkah kegiatan yang akan dilakukan. Terakhir adalah kepemimpinan ketua kelompok yang bersifat multifungsi yaitu sebagai penguat kelompok, pengarah anggota, penggerak kegiatan serta menyelesaikan konflik-konflik internal 


\section{DAFTAR PUSTAKA}

Departemen Sosial RI. (2004). Pengembangan Usaha Ekonomi Produktif Fakir Miskin Melalui Kelompok Usaha

Bersama (KUBE) Dan Lembaga Keuangan Mikro (LKM). Jakarta

Departemen Sosial RI. (2005). Rencana Strategis Penanggulangan Kemiskinan Program Pemberdayaan Fakir Miskin Tahun 2006-2010. Jakarta.

Gunawan, Imam. 2013. Metode Penelitian Kualitatif: Teori dan Praktik. Jakarta: PT Bumi Aksara

Istiana, dkk. (2012). Evaluasi Program KUBE. Yogyakarta: B2P3KS Press.

Kelurahan Guntung. (2017). Monografi Kelurahan Semester II Juli S/D Desember 2017. Bontang: Kelurahan Lempake

KUBE Mekar Sari. (2016). Profil KUBE Mekar Sari. Bontang: KUBE Mekar Sari

Moleong Lexy, J. 2012. Metode Penelitian Kualitatif. Bandung: PT Remaja Rosdakarya.

Oos M, Anwas. 2013. Pemberdayaan Masyarakat Di Era Global. Bandung: Penerbit Alfabeta.

Patton, Adri. 2006. Perilaku Dan Pengembangan Organisasi. Malang: Agritek Yayasan Pembangunan Nasional.

Pace, R. Wayne dan Faules, Don F. 1998. Komunikasi Organisasi. Bandung: PT Remaja Rosdakarya Bandung

Republik Indonesia. (2010). Pedoman Kelompok Usaha Bersama. Jakarta: Kementerian Sosial RI.

Republik Indonesia. (2010). Pedoman Kelompok Usaha Bersama. Jakarta: Kementerian Sosial RI.

Seotomo. 2012. Keswadayaan Masyarakat. Yogyakarta: Pustaka Pelajar.

Sjafari, Agus. 2014. Kemiskinan Dan Pemberdayaan Kelompok. Yogyakarta: Graha Ilmu.

Sugiyono. 2014. Memahami Penelitian Kualitatif. Bandung: Penerbit Alfabeta.

Thoha, Miftah. 2002. Pembinaan Organisasi. Jakarta: PT RajaGrafindo Persada.

Zulkarnain, Wildan. 2013. Dinamika Kelompok (Latihan Kepemimpinan Pendidikan). Jakarta: PT Bumi Aksara.

Ayu Ningrum, Diah, 2017. Peran Kelompok Usaha Bersama (KUBE) dalam Menangani Kemiskinan di KUBE Sejahtera Desa Giripurno, Ngadirejo, Temanggung. Skripsi. Yogyakarta: Universitas Negeri Yogyakarta. dalam: https://journal.uny.ac.id/

Indrika, Ristinura, 2013. Pemberdayaan Masyarakat melalui Kelompok Usaha Bersama (KUBE) Tanjung dalam Meningkatkan Kualitas Hidup. Studi di Desa Wonokerso Tembarak Temanggung. Skrpsi. Yogyakarta: Universitas Negeri Yogyakarta. dalam: https://journal.uny.ac.id/

Lestari, Mugi, 2011. Dinamika Kelompok dan Kemandirian Anggota Kelompok Tani dalam Berusahatani di Kecamatan Pancowaro Kabupaten Kebumen Propinsi Jawa Tengah. Tesis. Surakarta: Universitas Sebelas Maret. dalam: https://jurnal.uns.ac.id/

Tampubolon, Joyakin, 2006. Pemberdayaan Masyarakat Melalui Pendekatan Kelompok Kasus Pemberdayaan Masyarakat Miskin melalui Pendekatan Kelompok Usaha Bersama (KUBE). Disertasi. Bogor: Institut Pertanian Bogor. dalam : https://repository.ipb.ac.id/

Akses Internet

Istiana Hermawati. (2006). Ujicoba Model KUBE dalam Pengentasan Keluarga Miskin. Yogyakarta: Balai Besar Penelitian dan Pengembangan Pelayanan Kejahteraan (bbp3ks.kemsos.go.id/modules.php?name=News\&file=article\&sid=107) $\quad$ diakses $\quad$ pada $4 \quad$ April 2018 https://www.facebook.com/groups/665489166926641/ diakses 4 April 2018 ppid.bontangkota.go.id/35-kube-dan-5kelompok-rtlh-dibekali-bimtek/ diakses pada 4 April 2018

http://www.klikbontang.com/berita-10741-kube-mekar-sari-bontang-jadi-terbaik-kube-nasional.html diakses pada 4 April 2018 https://kaltim.antaranews.com/berita/7273/dissosnaker-bontang-tumbuhkan-lima-kube-daerah-pesisir diakses pada 4 April 2011 Tim Penyusun. (2005). Peraturan Direktur Jenderal Perbendaharaan Nomor Per-19/Pb/2005 Tentang 
Petunjuk Penyaluran Dana Bantuan Modal Usaha Bagi Keluarga Binaan Sosial Program Pemberdayaan Fakir Miskin Melalui Pola Pengembangan Terpadu Kelompok Usaha Bersama (KUBE) Dan Lembaga Keuangan Mikro (LKM).

Diakses dari (http://www.balimaknews.net/2010/FTP/peraturan/perdirjend/perdirjen_19_2005.pdf), pada 5 Juli 2018.

Dinas Sosial Provinsi Yogyakarta. (2010). KUBE Program Strategis Dinas Sosial dalam Pengentasan Kemiskinan.

Diakses dari (http://www.p2kp.org/warta/files/dinsos DIY_PAPARAN\%20_KUBE.pdf), pada tanggal 5 Juli 2018.

https://www.kemsos.go.id/ diakses pada 6 mei 2018

https://bontangkota.bps.go.id/ diakses pada 6 mei 2018

http://dinsos.jogjaprov.go.id/kelompok-usaha-bersama-kube-berkumpulnya-orang miskin-untuk-mandiri/ diakses pada 5 Juni 2018

http://pktvbontang.com/pkt-bekali-kube-mekar-sari-tata-kelola-manajemen-keuangan/ diakses pada 7 Juni 2018

https://kaltim.antaranews.com/berita/43834/pupuk-kaltim-mengantar-kube-mekar-sari-menuju-kemandirian-masyarakat diakses pada 7 Juni 2018

http://kaltimprov.go.id/berita/-kube-kaltim-raih-terbaik-pertama-nasional-2016

diakses pada 7 Juni 2018 